Anuario Latinoamericano Ciencias Políticas

y Relaciones Internacionales

vol. 4, 2017

pp. 105-117

\section{"Project Deliverance": a case study on the relevance of task forces against transnational criminal organizations in U.S.-Mexican relations}

\begin{abstract}
"Proyecto Liberación": un estudio de caso sobre la relevancia de las fuerzas de tarea contra las organizaciones criminales transnacionales en las relaciones México-Estados Unidos
\end{abstract}

\author{
Agustín Maciel-Padilla \\ EMBASSY OF MEXICO IN BELIZE \\ 3 NORTH RING ROAD, BELMOPAN, CAYO, BELIZE \\ $\triangle$ maciel.agustin@gmail.com
}

\begin{abstract}
This is a case study on the advantages of task forces in the fight against drug trafficking in U.S.-Mexican relations. This analysis focuses on the 2010 "Project Deliverance" that at the time was considered one of the most successful initiatives against Mexican drug trafficking networks within the United States based on the operation of task forces, as well as on the collaborative bilateral atmosphere created by the Merida Initiative (MI) to achieve positive outcomes. It addresses the Southwest Border Security Initiative (SBSI), and finally the task force-structure that allowed "Project Deliverance" to be effective.
\end{abstract}

KEYWORDS: task forces, drug trafficking, drug networks, U.S.-Mexican relations.

\section{RESUMEN}

Este es un estudio de caso sobre las ventajas de las fuerzas de tarea en la lucha contra el tráfico de drogas en las relaciones México-Estados Unidos. El análisis se

\footnotetext{
1 Dr. Agustín Maciel-Padilla has extensive experience in the Mexican public sector and in academia both in Mexico and the United States. His activities in public service have focused on the analysis of foreign policy issues, national security, borders, and transnational illicit flows. His expertise has also included social communication, technical-scientific cooperation and negotiation. In his career in the academic field, he has been professor-researcher on national security studies and intelligence, administrator of academic programs, and guest lecturer in national and foreign institutions on Mexico's national security and security in U.S.-Mexican relations. He has been an independent consultant.
} 


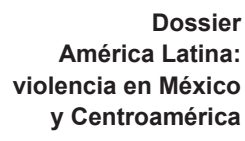

América Latina:

violencia en México

y Centroamérica centra en el "Proyecto Liberación" de 2010, el cual en su momento fue considerado como una de las iniciativas más exitosas contra las redes mexicanas de tráfico de drogas en los Estados Unidos con base en la operación de fuerzas de tarea, así como en una atmósfera bilateral de colaboración creada por la Iniciativa Mérida (MI) para alcanzar resultados positivos. El artículo aborda la Iniciativa de Seguridad de la Frontera Suroeste (SBSI), y finalmente la estructura de la fuerza de tarea que dio efectividad al "Proyecto Liberación".

PALABRAS CLAVE: fuerzas de tarea, tráfico de drogas, redes del narcotráfico, relaciones México-Estados Unidos.

\section{Introduction}

The phenomenon of organized crime is not new, and it has developed considerably in the last decades. It has grown in scope and scale as the result of both the process of globalization - meaning the intensification of trade, information, and transportation connections around the world-, and the end of the Cold War and its impact on bringing down barriers and the emergence of new democracies, some of them with fragile institutions (Stephens 1996).

Currently, there is a wide range of criminal activities conducted across borders that prompted the gradual reconceptualization of national security from its traditional focus on state (military) threats to the challenges posed by non-state actors (Buzan, Weaver, De Wilde 1997). Transnational organized crime (TOC) $)^{2}$ refers to activities with an international dimension such as drug, human and arms trafficking, money laundering and smuggling of a variety of goods, among others, in a process that involves several jurisdictions that in turn impose the need for governments to collaborate in order to address these challenges.

According to the United Nations (UN), new trends in organized crime point to a transition from hierarchical organizations to non-structured groups. That is, the phenomenon is increasingly characterized by the activities of loose networks taking advantage of adaptability and a low-profile. Furthermore, organized crime is less about individuals and more about a range of illicit activities, and this is the reason why despite significant efforts by authorities to capture its leaders and seize their assets, criminal activities continue unabated by the profits created by the illicit market (UNDOC 2010).

2 Even though the United Nations Convention against Transnational Organized Crime (UNTOC) does not provide a specific definition of "transnational organized crime" in order to allow for a broader applicability of the legal instrument, it does propose a definition of 'organized criminal group': a) a group of three or more persons that was not randomly formed; b) existing for a period of time; c) acting in concert with the aim of committing at least one crime punishable by at least four years' incarceration; and d) in order to obtain, directly or indirectly, a financial or other material benefit (UNDOC 2016). 
The combination of global transformations and the mutation of organized crime towards the prevalence of networks pose a challenge to the governments' efforts to contain criminal activities because of insufficient official coordination at the international level to deal with the problem (CIGI 2010). In this context, it is recognized that it is difficult for a country individually to respond to a threat that has connections across several jurisdictions. To be effective, therefore, the response must be coordinated and the result of collaboration.

The value of cooperation resides in its ability to overcome the limitations of individual organizations by creating "multidisciplinary" groups with strategic capacity to address specific threats, and this is the logic behind the creation of task forces (OVC-TTAC/b). "Task force" is a term originating in the armed forces lexicon to refer to a "force organized for a special operation" or "a unit specially organized for a task" (Oxford English Dictionary). For instance, regarding human trafficking, the objective of a task force consists in tackling a complex problem by planning and developing coordinated and integrated responses, and by anticipating the needs of all stake-holders becoming thus a valuable resource for anti-trafficking efforts (Oxford English Dictionary).

Because of the fact that it is easier to conceive cooperation than to achieve it, this is the reason why organizing a task force represents a challenge in itself. In task forces, partnership is the most valuable resource, and their advantages are, among others, to create a pool of information members can share; to create an environment where agencies learn about each other facilitating thus strategic planning; and to gain knowledge about the roles and capacities of partners that allows participants to recognize the value of collaboration (OVC-TTAC/a).

Taking into consideration the elements above, the objective of this essay is to present a case study on the advantages of task forces in the fight against Mexican drug trafficking in the United States. In particular, this analysis is based on a case study methodology where the objective is "learn[ing] to identify actual problems, to recognize key players and their agendas, and to become aware of those aspects of the situation that contribute to the problem" (Becker et al. 1994-2012). . This analysis focuses on the 2010 "Project Deliverance" that at the time was considered one of the most successful initiatives against Mexican drug trafficking networks within the United States based on the operation of task forces, as well as on the collaborative bilateral atmosphere created by the Merida Initiative (MI) to achieve positive outcomes. It addresses the Southwest Border Security Initiative (SBSI), and finally the task force structure that allowed "Project Deliverance" to be effective.

\footnotetext{
3 Case study is a form of qualitative descriptive research that is based on the "collection and presentation of detailed information" about a particular subject or phenomenon with the aim not of reaching generalizations but instead to emphasize "exploration and description". The objective consists in examining the interplay of variables in order to gain an understanding of an issue as complete as possible (Becker et al. 1994-2012).
}

"Project Deliverance": a case study on the relevance of task forces against transnational criminal organizations in U.S.-Mexican relations

Agustín Maciel-Padilla 


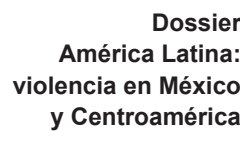

Dossier lencia en México y Centroamérica

\section{Drugs in U.S.-Mexican relations}

The United States and Mexico have a complex bilateral relationship that has been characterized by the intensity of its economic interaction, which only grew stronger under the 1994 North America Free Trade Agreement (NAFTA). ${ }^{4}$ After the $9 / 11$ terrorist attacks, nevertheless, security issues made it to the top of the bilateral agenda, even though security cooperation between the two countries had been present for decades, mainly focusing on drug trafficking as the most controversial issue for the two neighbors sharing a 2.000mile border (Craig 1989).

While the United States has been the dominant economic power and the biggest drug market in the world, its neighbor to the south has been a developing country that has also been a major producer and supplier of marijuana, heroin and methamphetamine, and the major transit point for $95 \%$ of the cocaine entering the United States (ONDCP 2012: 2). By 2009, it was estimated that the value of the US drug market for the Mexican drug trafficking organizations (DTOs) was between $\$ 18$ and $\$ 39$ billion (NDIC 2009: iii) and, as a matter of fact, according to the 2010 National Drug Threat Assessment, "Mexican DTOs [continued] to represent the single greatest drug trafficking threat to the United States" (NDIC 2010: 2).

Given the challenge drug trafficking has posed to Mexico itself, and the official argument at the time that the previous administration had not done enough to confront the problem (Expansión 2016), after taking office in December 2006 President Felipe Calderon made combating DTOs a top priority of his administration. As a relevant component of his strategy, he set out to build international partnerships, especially with the United States. Moreover, he favored the extradition of drug traffickers, sending a record number of 107 individuals abroad by 2009 (Seelke, Sullivan, Beittel 2010: 6). ${ }^{5}$

In a bilateral summit between President Calderon and President George W. Bush that took place in Mérida, Yucatán, the United States and Mexico issued a joint statement on October 22, 2007, announcing a three-year plan for $\$ 1,4$ billion in U.S. assistance (comprising only equipment and training) to Mexico and Central American countries to confront transnational crime known as the MI that would begin in FY2008. It was based on the principles

\footnotetext{
4 The economic relationship with Mexico has been relevant for the United States, for instance, "because of Mexico's proximity to the United States, the high level of bilateral trade, and the strong cultural and economic ties that connect the two countries. Also, it is of national interest for the United States to have a prosperous and democratic Mexico as a neighboring country. Mexico is the United States' third-largest trading partner, while the United States is, by far, Mexico's largest trading partner. Mexico ranks third as a source of U.S. imports, after China and Canada, and second, after Canada, as an export market for U.S. goods and services. The United States is the largest source of foreign direct investment (FDI) in Mexico" (Villareal 2015).

5 Between 2000 and 2005, the Mexican government extradited 160 individuals, in contrast to the 464 extraditions between 2006 and 2011, which represented a 190\% increase (Gutiérrez 2011).
} 
of "shared responsibility, mutual trust and respect for sovereign independence" (DOS 2010), and its four pillars consisted in: disrupting organized crime groups; strengthening institutions; building a $21^{\text {st }}$ century border; and building strong and resilient communities (DOS 2010).

MI was an unprecedented partnership between the two countries, and two important points are in order: first, it was developed in response to the Mexican government's request for U.S. support to deal with drug trafficking; prior to this time, bilateral antinarcotics collaboration had been maintained at a minimum by Mexican authorities and efforts were often obstructed by suspicion because of corruption in Mexico (U.S. assistance to Mexico went from $\$ 65,4$ million in FY2007 to \$786,8 million in FY2009) (Seelke, Sullivan, Beittel 2010: 12); second, the U.S. government strengthened intelligence exchange with Mexico in order to support law enforcement and military anti-drug operations in the country (Seelke, Finklea 2016: 10), a practice that had also been difficult to promote because of the reasons above. Ever since its inception, it has been problematic to measure the success of the MI and the most common method of evaluation has consisted in counting equipment delivered and training activities carried out, even though the pace of both has occasionally slowed down because of human rights concerns regarding Mexico. A General Accountability Office (GAO) report, nevertheless, pointed out the Department of State, the organization in charge of the overall coordination of the program, found it difficult to design the "performance measures" to determine the achievement of the MI's strategic goals. For instance, the number of Mexican agents trained under the initiative has not automatically translated into more effective law enforcement in Mexico (Olson, Wilson 2010: 1), and has not guaranteed the more efficient use of resources either.

\section{Southwest Border Security Initiative (SBSI)}

Because drug-violence in several areas of Mexico had escalated as a result of increasing pressure by the Mexican government, DTOs intensified the fight against each other for the control of "plazas" and lucrative routes to the United States. Nevertheless, the fight was not only among DTOs and against Mexican security forces, but also within the organizations themselves as a result of the fragmentation created by the Mexican government's so-called "Kingpin" strategy that took on the leadership of the organizations in order to erode their structures (Hamilton 2013). It is estimated that there were around 60.000 drug-related deaths during the Calderon Administration (Seelke 2013).

Against this background, on March 24, 2009, the Obama Administration announced its SBSI to strengthen security along the border with Mexico (DHS 2009), in part out of concern about a possible violence spill-over across the border (Burnett 2011). The objective of this plan was to contain the trans-border flow of drugs (northward), cash and guns (southward) fostering this violence.
"Project Deliverance": a case study on the relevance of task forces against transnational criminal organizations in U.S.-Mexican relations

Agustín Maciel-Padilla 




Dossier violencia en México y Centroamérica
Enhancing border security required a set of measures that revolved around deploying additional personnel to the area, increasing intelligence capabilities and strengthening coordination among security agencies both domestically and internationally. Two departments were responsible for implementing actions in support of border security. On the one hand, the Department of Homeland Security (DHS) emphasized information sharing and integration with state and local law enforcement agencies, and also with Mexican authorities. For instance, DHS increased the number of Immigration and Custom Enforcement (ICE) Attaché personnel working in hot spots in Mexico such as Ciudad Juárez, and the number of Border Liaison Officers working with Mexico (DHS 2009). In order to increase information-sharing and coordination, it also expanded Mexican law enforcement participation in Border Enforcement Security Task Forces (BEST) located in the southwest border region, and on August 13, 2009, it announced the creation of the first-ever Mexico City's BEST (ONDCP 2010: 25).

On the other hand, the Department of Justice (DOJ) reallocated personnel to both combat Mexican drug cartels in the United States and to work closely with Mexican law enforcement agencies. One key aspect was the formulation of a "Mexican Cartel Strategy" (ONDCP 2010: 13) under the Office of the Deputy Attorney General that relied on "federal prosecutor-led task forces" in order to combine all law enforcement components to dismantle and disrupt Mexican drug cartels through investigation, prosecution, extradition and forfeiture of their assets. As established by the then-Assistant Attorney General, Criminal Division, Lenny A. Breuer:

For more than a quarter-century, the principal law enforcement agencies in the United States have recognized that the best way to fight the most sophisticated and powerful criminal organizations is through intelligencebased, prosecutor-led task forces that leverage the strength, resources, and expertise of the complete spectrum of federal, state, local and international investigative and prosecutorial agencies (Breuer 2009: 12).

One relevant aspect of the fight against DTO networks within the United States was the strengthening of the Organized Crime Drug Enforcement Task Force (OCDETF) capacity along the southwest border. The OCDETF program was established in 1982 in order to deal with drug trafficking from a comprehensive perspective, becoming the centerpiece of the U.S. Attorney General's anti-drug strategy in the United States. It was an effort that combined resources and expertise from several federal agencies (DEA, ATF, IRS, USCG, ICE, USMS, DOJ Criminal and Tax Divisions and 94 U.S. Attorney General Offices) under the direction of the Deputy Attorney General, who also coordinated the Annual Consolidated Priority Organization Target (CPOT)-List and, with the support of the OCDETF Fusion Center, focused on multijurisdictional investigations (DOJ 2009). As it will be discussed be- 
low, it was this organizational structure the key that allowed "Project Deliverance" to be effective.

Months after the announcement of the SBSI, the Office of National Drug Control Policy (ONDCP) published the 2009 National Southwest Border Counternarcotics Strategy, a document produced every two years starting in 2007. This strategy has represented a central component of the U.S. response to threats along the border with Mexico by defining the responsibilities of U.S. agencies in the region. By the time of its publication, President Calderón had already embarked on the campaign to fight drug cartels in Mexico, and through the MI the U.S. was supporting Mexican law enforcement and judicial reform efforts. Due to the significant increase of violence in the country, the 2009 strategy modified its focus from containing the inbound flow of illegal drugs from the southwest border to also contain the flow of illegal weapons and cash into Mexico, while coordination with Mexican authorities was strengthened (ONDCP 2009: i).

The strategic goal defined in the document consisted in "substantially reduce the flow of illicit drugs, drug proceeds, and associated instruments of violence across the southwest border", while also strengthening intelligence and interdiction capabilities, as well as increasing the efficiency of prosecution of criminals and U.S.-Mexico cooperation (ONDCP 2009: 2).

In the area of intelligence, in particular, the strategy provided for the reestablishment of the Interagency Working Group on Intelligence Coordination (IWG-IC) co-chaired by the DEA Office of Intelligence and DHS Office of Intelligence Analysis (ONDCP 2009: 6). The DEA and the Intelligence Community also co-chaired the U.S.-Mexico bilateral High Value Target Working Group (HVTWG), where Mexican federal agencies coordinated the exchange of intelligence (ONDCP 2010: 5), in contrast to previous occasions when sharing information with Mexico had proven difficult. In the area of investigation and prosecution, U.S. law enforcement and intelligence would combine resources in order to support these efforts domestically and bilaterally.

U.S. and Mexican law enforcement and intelligence communities must closely coordinate their efforts to disrupt and dismantle criminal organizations responsible for the movement of illicit drugs, firearms, and drug proceeds across the Southwest border by building strong cases against these organizations and bringing their leadership to justice (ONDCP 2010: 21).

In this context, the specific purpose of U.S. law enforcement collaborating with Mexico through reinforcing the liaison presence in the country was to support investigations and prosecution of drug traffickers. Domestically, improving coordination between the Office of Foreign Assets Control (OFAC) and U.S. law enforcement agencies and task forces consisted in increasing the capacity to disrupt the DTOs financial operations. Within this framework, U.S. Attorney Offices represented an essential element in the comprehensive
"Project Deliverance": a case study on the relevance of task forces against transnational criminal organizations in U.S.-Mexican relations

Agustín Maciel-Padilla 
Dossier América Latina: violencia en México y Centroamérica strategy to deal with drug trafficking along the southwest border, and therefore the importance of making them available to support OCDETF task forces (ONDCP 2010: 22). In a wider context, MI activities were instrumental, by building mutual trust, in reinforcing law enforcement and judicial cooperation to take on complex investigations and prosecutions.

\section{"Project Deliverance"}

Taking advantage of the law enforcement structure that had been put in place, and building on the success of previous operations against Mexican cartels, ${ }^{6}$ the U.S. Government launched "Project Deliverance".

On June 10, 2010, then-Attorney General Eric Holder announced the completion of a 22-month investigation that focused on the transportation infrastructure of Mexican DTOs in the United States, especially along the southwest border, through the coordination between state and local law enforcement. According to Holder, "this interagency, cross-border operation has been our most extensive, and most successful, law enforcement effort to date targeting these deadly cartels, and it is a direct result of our ongoing Southwest Border Strategy" (DOJ 2010: 1). The structure of "Project Deliverance" was characterized by strong investigative capabilities coordinated by the DEA Special Operations Division comprising personnel from different federal agencies as well as Attorneys from DOJ's Criminal Division's Narcotic and Dangerous Drug Section. This operation was carried out by more than 300 agencies from the three levels of government in the United States, some of them participating through High Intensity Drug Trafficking Area (HIDTA) and OCDETF task forces, with the support from the Criminal Division's Office of International Affairs.

The reason why the objective of "Project Deliverance" focused on dealing with the network of facilitators and transportation infrastructure of Mexican DTOs operating in the United States was the fact that, by that time, these organizations were practically present in every region of the country and active in a significant number of cities. Moreover, in previous years they had been able to expand along the Atlantic coast, displacing Colombian cocaine and heroin traffickers there, while at the same time had consolidated their presence by increasing their transportation and distribution networks (NDIC 2010: 9).

Mexican DTOs also strengthened their operations in the United States by establishing alliances with U.S. gangs in order to distribute drugs. It is estimated that since 2001, street gangs in the United States have experienced a gradual transformation from their traditional role as local retail drug suppliers,

6 Consider, for instance, "Project Reckoning" leading to the arrest of 600 individuals related to the Gulf/Los Zetas Cartel; "Operation Xcellerator" against the Sinaloa cartel resulting in 700 members detained; and "Operation Coronado" against La Familia Michoacana producing 1.200 people arrested and significant quantities of drug and proceeds seizures, all within U.S. territory. 
mainly in urban areas, to become wholesale distributors, displacing in the process small, local, criminal groups. This structural change was possible as Hispanic and African-American gangs began acquiring drugs directly from DTOs in Mexico and along the southwest border. Buying directly from Mexican traffickers allowed gangs to sell drugs at lower prices than local dealers, driving them thus out of the market. A similar process occurred with Hispanic prison gangs, primarily in southwest border states which also have had extensive links, if not control, over street gangs. By 2009, it was estimated that retail drug supply in the United States was controlled by more than 900.000 members from 20.000 gangs in more than 2.500 cities (NDIC 2010: 12-13).

\begin{tabular}{ccc}
\hline Project Deliverance & June 9,2010 & Overall \\
\hline Arrests & 429 & 2266 \\
US currency & $\$ 5,8$ million & $\$ 154$ million \\
Cocaine & 112 kilograms & 2,5 tons \\
Heroin & 92 pounds & 1.410 pounds \\
Meth & 17 pounds & 1.262 pounds \\
Marijuana & 2.951 pounds & 69 tons \\
Weapons & 141 & 501 \\
Vehicles & 85 & 527 \\
\hline
\end{tabular}

Source: DOJ 2010a.

Mexican law enforcement agencies collaborated with the United States as part of "Project Deliverance", in particular, by providing support in the arrest of Carlos Ramon Castro-Rocha, a heroin trafficker who had been designated a CPOT in relation to heroin shipments to the United States. Castro-Rocha was arrested in the state of Sinaloa on May 30, 2010, in response to arrest warrants from U.S. District Courts from Western North Carolina and Arizona, and accusations against the members of his organization referred to conspiracy to distribute and to import drugs into the United States (FBI 2014).

According to Mexican authorities, bilateral cooperation and exchange of information resulted in the arrest of Castro-Rocha, one of the main targets of "Project Deliverance". Intelligence reports produced since 2002 pointed out he was investigated for large-scale production and export of heroin and that he controlled groups in more than 10 U.S. cities, including Los Angeles and San Diego, and was related to 40 investigations both in Mexico and in the United States (PGR-SSP 2010). He was "one of the largest distributors of heroin in the United States" (Markin 2010), moving it from Guasave, Sinaloa. As he
"Project Deliverance": a case study on the relevance of task forces against transnational criminal organizations in U.S.-Mexican relations

Agustín Maciel-Padilla

Table 1.

"Project Deliverance" in numbers 
Dossier América Latina: violencia en México y Centroamérica had usually maintained a low-profile, and because he was not a member of a known cartel, his capture had always been elusive. "Project Deliverance", nevertheless, underlined the relevance of the bilateral exchange of information that allowed for the development of the investigation.

\section{Lessons learned}

Around the end of the decade of the 2000s, a powerful incentive to review bilateral security cooperation was created by increasing drug violence in Mexico and the prospect for border violence spilling over into the United States. In this context, the MI created the framework for improving bilateral security cooperation as reflected in greater law enforcement cooperation. A bilateral exchange of intelligence structure was created based on a closer collaboration between U.S. law enforcement agencies and vetted units from Mexico.

Targeting the drug transportation networks and mid-level facilitators within the United States disrupted their operations by slowing down their pace, and hitting at the mid-level ranks of the organizations, in particular, generated instability within by fostering disarray and internal competition. It also allowed U.S. law enforcement agencies to obtain valuable information about the network's upper and lower echelons, and this became the building block for further counterdrug operations.

As discussed at the beginning of this essay, nevertheless, organized crime and drug trafficking by inference is increasingly becoming about loose networks that carry out criminal activities in return of significant profits. In this context, as much as "Project Deliverance" was touted as a "successful" operation, at the end of the day drug trafficking across the U.S.-Mexico border has not been disrupted basically because the market forces of supply and demand remain intact. Therefore, the long-term objective of U.S.-Mexico counterdrug efforts should focus not on record numbers of arrests and seizures but on transforming the structure of the drug market, by reducing demand or by limiting the profitability of the illegal commodity. 


\section{Bibliography}

Alzaga I. (2014), Ejército despojó al narco 22 mdd este año (gráfica). Decomisó también 37 mdp $y$ detuvo a 5 mil 581 sujetos en flagrancia. Además confiscó 4 mil 50 armas largas, 2 mil 25 pistolas y 617 granadas, sipse.com, 22.12.2014, available at: http://sipse.com/mexico/reporte-sedenadecomisos-aseguramientos-narcotrafico-2014-128804.html10.06.2010, access: 06.08.2016.

Becker B. et al. (1994-2012), Case Studies. Writing Guide, Colorado State University, available at: http://writing.colostate.edu/guides/pdfs/guide60.pdf, access: 06.12.2016.

Breuer L. A. (2009), The Rise of Mexican Drug Cartels and U.S. National Security, Statement before the United States House of Representatives, Committee on Oversight and Government Reform, available at: https://www.scribd.com/document/118269731/Statement-of-LannyBreuer-William-Hoover-and-Anthony-Placido-before-the-US-House-of-RepresentativesCommittee-on-Oversight-and-Government-Reform, access: 05.09.2016.

Burnett J. (2011), 'Spillover' Violence from Mexico. Trickle or Flood?, National Public Radio, 06.07.2011, available at: http://www.npr.org/2011/07/06/137445310/spillover-violencefrom-mexico-a-trickle-or-flood, access: 06.09.2016.

Buzan B., Weaver O., De Wilde J. (1997), Security. A New Framework for Analysis, Lynne Rienner Pub., Boulder CO.

CIGI, Centre for International Governance Innovation (2012), Global Governance and the Challenge of Transnational Organized Crime: The Role of the Constructive Powers, conference report, 05-07.09.2012, Mexico City, available at: https://www.cigionline.org/sites/ default/files/cpi_mexico_city_rev1.pdf, access: 22.09.2016.

Craig R. B. (1989), U.S. Narcotics Policy toward Mexico. Consequences for the Bilateral Relationship, in: González G., Tienda M. (eds.), The Drug Connection in U.S.-Mexican Relations, Bilateral Commission on the Future of United States-Mexican Relations, Center for U.S.Mexican Studies, University of California, San Diego CA.

DHS, Department of Homeland Security (2009), Secretary Napolitano Announces Major Southwest Border Security Initiative, Office of the Press Secretary, 24.03.09, available at: https://www.dhs.gov/news/2009/03/24/napolitano-announces-major-southwest-bordersecurity-initiative, access: 22.09.16.

DOJ, Department of Justice (2009), Department of Justice Announces Resources for Fight against Mexican Drug Cartels, Office of Public Affairs, available at: https://www.justice.gov/ opa/pr/department-justice-announces-resources-fight-against-mexican-drug-cartels, access: 05.09.2016.

DOJ, Department of Justice (2010), Attorney General Eric Holder Speaks at the "Project Deliverance" Press Conference, Office of Public Affairs, available at: https://www.justice.gov/ opa/speech/attorney-general-eric-holder-speaks-project-deliverance-press-conference, access: 05.09.2016.

DOJ, Department of Justice, (2010a), "Project Deliverance" Results in More Than 2.200 Arrests During 22-Month Operation, Seizures of Approximately 74 Tons of Drugs and \$154 Million in U.S. Currency, Office of Public Affairs, available at: https://www.justice.gov/opa/ pr/project-deliverance-results-more-2200-arrests-during-22-month-operation-seizures, access: 06.10.2010.

DOS, Department of State (2010), United States-Mexico Security Partnership. Progress and Impact, Office of the Spokesman, 23.03.2010, Washington D.C., available at: http://www. state.gov/r/pa/prs/ps/2010/03/138929.htm, access: 16.08.2016.
"Project Deliverance": a case study on the relevance of task forces against transnational criminal organizations in U.S.-Mexican relations

Agustín Maciel-Padilla 


\section{Dossier América Latina: violencia en México y Centroamérica}

FBI, Federal Bureau of Investigation (2014), Mexican Drug Kingpin Pleads Guilty to Trafficking Black Tar Heroin, U.S. Attorney's Office, Western District of North Carolina, 28.04.2014, available at: https://www.fbi.gov/contact-us/field-offices/charlotte/news/press-releases/mexican-drug-kingpin-pleads-guilty-to-trafficking-black-tar-heroin, access: 06.12.2016.

Gutiérrez G. (2011), Se dispara en sexenio extradición de narcos, “El Universal”, 12.12.2011, available at: http://archivo.eluniversal.com.mx/primera/38346.html, access: 06.12.2016.

Hamilton K. (2013), Why Killing Kingpins Won't Stop Mexico's Drug Cartels, "The Atlantic", 27.02.13, available at: http://www.theatlantic.com/international/archive/2013/02/whykilling-kingpins-wont-stop-mexicos-drug-cartels/273558/, access: 16.08.2016.

Markin J. (2010), More Than 2.200 Arrested in Crackdown on Mexican Drug Cartels, “The Washington Post”, 10.06.2010, available at: http://www.washingtonpost.com/wp-dyn/content/article/2010/06/10/AR2010061002074.html, access: 06.09.2016.

NDIC, National Drug Intelligence Center (2009), National Drug Threat Assessment 2009, US Department of Justice, Washington D.C. available at: https://www.justice.gov/archive/ ndic/pubs31/31379/31379p.pdf, access: 16.08.2016.

NDIC, National Drug Intelligence Center (2010), National Drug Threat Assessment 2010, US Department of Justice, Washington D.C. available at: https:/www.justice.gov/archive/ ndic/pubs38/38661/38661p.pdf, access: 16.08.2016.

Olson E. L., Wilson C. E. (2010), GAO Report Finds Merida Initiative Needs Better Performance Measures. Pace of Delivery Slow but Improving, Mexico Institute, Woodrow Wilson International Center for Scholars, available at: https://www.wilsoncenter.org/sites/default/files/GAO\%20 Report\%20Finds\%20Merida\%20Initiative\%20Needs\%20Better\%20Performance\%20Measures, \%20Pace\%20of\%20Delivery\%20Slow\%20but\%20Improving.pdf, access: 06.12.2016.

ONDCP, Office of National Drug Control Policy (2009), National Southwest Border Counternarcotics Strategy, Washington D.C. available at: https://www.whitehouse.gov/ sites/default/files/ondcp/policy-and-research/swb_counternarcotics_strategy09.pdf, access: 06.09.2016.

ONDCP, Office of National Drug Control Policy (2010), National Southwest Border Counternarcotics Strategy Implementation Update, Washington D.C. available at: https:/www. whitehouse.gov/sites/default/files/ondcp/policy-and-research/swb_implementation10_0. pdf, access: 05.09.2016.

ONDCP, Office of National Drug Control Policy (2012), Cocaine Smuggling in 2010, Washington D.C., available at: https://www.whitehouse.gov/sites/default/files/ondcp/international-partnerships-content/20_january_cocaine_smuggling_in_2010_for_posting_on_ ondcp_webpage_2.pdf, access: 22.09.2016.

OVC-TTAC/a, Office for Victims and Crime, Training and Technical Assistance Center, Advantages of a Task Force, available at: https://www.ovcttac.gov/taskforceguide/eguide/2forming-a-task-force/21-advantages-of-a-task-force/, access: 05.09.2016.

OVC-TTAC/b, Office for Victims of Crime, Training and Technical Assistance Center, Forming a Task Force, available at: https://www.ovcttac.gov/taskforceguide/eguide/2-forminga-task-force/, access: 05.09.2016.

Oxford English Dictionary, available at: https://en.oxforddictionaries.com/definition/us/ task_force, access: 06.12.2016.

PGR-SSP (2010), Procuraduría General de la República, Secretaría de Seguridad Pública, SSP y PGR capturan a Carlos Ramón Castro, alias 'El Cuate', Youtube, available at: https:// www.youtube.com/watch?v=0bIvv6BHhpc, access: 06.09.2016. 
Seelke C. R (2013), U.S.-Mexico Security Cooperation: An Overview of the Mérida Initiative 2008-Present", Testimony before Congress, 23.05.2013, Congressional Research Service (CRS), Washington D.C., available at: http://docs.house.gov/meetings/FA/FA07/20130523/100907/ HHRG-113-FA07-Wstate-SeelkeC-20130523.pdf, available [online]: 16.08.2016.

Seelke C. R., Finklea K., U.S.-Mexican Security Cooperation: The Mérida Initiative and Beyond, Congressional Research Service (CRS), 22.02.2016, Washington D.C., available at: https://www.fas.org/sgp/crs/row/R41349.pdf, access: 06.09.2016.

Seelke C. R., Sullivan M. P., Beittel J. S. (2010), Mexico-U.S. Relations: Issues for Congress, Congressional Research Service (CRS), Washington D.C., available at: fpc.state.gov/documents/organization/139243.pdf, access: 16.08.2016.

s/a (2016), Las diferencias en la política de drogas en los años de Fox, Calderón y Peña Nieto, "Expansión", 10.05.2016, available at: http://expansion.mx/nacional/2016/04/20/las-diferenciasen-la-politica-de-drogas-en-los-anos-de-fox-calderon-y-pena, access: 16.08.2016.

Stephens M. (1996), Global Organized Crime as a Threat to National Security, Woodrow Wilson School Policy Conference 401A, "Intelligence Reform in the Post-Cold War Era", 06.01.1996, available at: http://fas.org/irp/eprint/snyder/globalcrime.htm, access: 05.09.2016.

UNDOC, United Nations Office on Drugs and Crime (2010), The Globalization of Crime. A Transnational Organized Crime Threat Assessment, available at: https://www.unodc.org/ documents/data-and-analysis/tocta/TOCTA_Report_2010_low_res.pdf, access: 05.09.2016.

UNDOC, United Nations Office on Drugs and Crime (2016), Organized Crime, available at: https://www.unodc.org/unodc/ar/organized-crime/index.html, access: 06.12.2016.

Villareal M. A. (2015), U.S.-Mexico Economic Relations: Trends, Issues, and Implications, Congressional Research Service (CRS), 20.04.2015, Washington D.C., available at: https:// www.fas.org/sgp/crs/row/RL32934.pdf, access: 13.08.2016.
"Project Deliverance": a case study on the relevance of task forces against transnational criminal organizations in U.S.-Mexican relations

Agustín Maciel-Padilla 